\title{
Physiological quality of irrigated rice seeds benefited in different UBS in the internal coastal plain of Lagoa dos Patos
}

Cleo Soares, Cristina Rossetti, Andreia Almeida, Alejandro José de Melo, Diogo da Silva Moura, Ritieli Mambrin, Lilian Vanussa Madruga de Tunes

Universidade Federal de Pelotas - UFPel, RS. E-mail: cristinarosseti@yahoo.com.br

\begin{abstract}
The objective of the study is to evaluate the evolution of the physical and physiological quality of rice seeds throughout the processing process, analyzing the efficiency of the equipment used in three Seed Processing Units (UBS) to produce certified seeds, located in the region of the inner coastal plain of Lagoa dos Patos. We know that the seed has to be made in the field, starting with the choice of the area, providing a good management and controlling invaders, pests and diseases, but we believe that UBS has a very important role in seed quality, and this is the purpose of this study. Each unit with its equipment on its production line was analyzed. The cultivar IRGA $424 \mathrm{RI}$ was used in the three units, samples were taken at the exit of each equipment, tests for seedling emergence, germination, physical purity and determination of other contaminating species were carried out. A gradual increase in purity and germination was observed along the processing line in the three UBS's, except for the determination of weedy rice, where equipment was not efficient.
\end{abstract}

Keywords: Emergency; Oryza sativa L.; certification.

Qualidade fisiológica de sementes de arroz irrigado beneficiadas em diferentes UBS's da planície litorânea interna da Lagoa dos Patos.

\section{Resumo}

O objetivo do estudo, é avaliar a evolução da qualidade física e fisiológica das sementes de arroz ao longo do processo de beneficiamento, analisando a eficiência dos equipamentos utilizados em três Unidades de Beneficiamentos de Sementes (UBS), de produção de sementes certificadas, localizadas na região da planície costeira interna da Lagoa dos Patos. Sabemos que a semente tem que ser feita no campo, começando pela escolha da área, proporcionando um bom manejo e controlando as invasoras, pragas e doenças, mas acreditamos que a UBS tem um papel muito importante na qualidade da semente e este é o propósito deste estudo. Foram analisadas cada unidade com seus equipamentos em sua linha de produção. Utilizou-se a cultivar IRGA $424 \mathrm{RI}$ nas três unidades, as amostras foram feitas na saída de cada equipamento, realizou-se os testes de emergência de plântulas, germinação, pureza física e determinação de outras espécies contaminantes. Observou-se um aumento gradativo na pureza e germinação ao longo da linha de beneficiamento nas três UBS's, exceto na determinação de arroz daninho, onde equipamentos não se mostraram eficientes.

Palavras-chave: Emergência; Oryza sativa L.; certificação.

\section{Introduction}

The seed is considered the most important agricultural input, because it takes with it genetic characteristics that determine the performance of the cultivar, being responsible for the good establishment of the crop. The use of good quality seeds of known origin is one of the main points to be considered in order to increase the productivity and profitability of the crop. Some factors are determinant in the production of quality seeds, sowing time, growing region and history of the area, this must be the first 
cultivation with rice or decontaminated with fallow or crop rotation, also, if applicable, control chemical or manual cleaning to remove contaminating plants, carry out phytosanitary treatments and pest control (IRGA, 2019).

To ensure minimum germination, physical and genetic purity, the seeds go through the certification process where they must meet the minimum quality standards determined by MAPA. Seed certification was instituted by Law 9456/1997 for the protection of cultivars and later regulated the production of seeds and seedlings with Law 10711/2003. Here in Rio Grande do Sul, the Secretariat of Agriculture, Livestock and Rural Development is responsible for the inspection work, and the Rio Grandense do Arroz Institute (IRGA), as part of this secretariat, is the Certifying Entity accredited by the Ministry of Agriculture, Livestock and Supply (MAPA). The senior rice technician, assisted by the rice technicians, is responsible for certifying the fields, collecting, analyzing samples, and issuing seed certificates. In addition to the cultivars developed by the institution, the IRGA is also responsible for the certification of cultivars developed by other breeders (IRGA, 2016).

In the region of the Internal Coastal Plain of Lagoa dos Patos, today, it has five rice seed processing units with production of certified seeds. The seed crops in this region are in the municipalities of Eldorado, Tapes, Arambaré and Camaquã, most of the crops in the region are installed in areas, with soybean as a predecessor crop, used for soil decontamination of invading plants resistant to chemical groups of herbicides and nutrient cycling. In some cases, areas considered decontaminated may be repeated with this cultivar. The cultivar most used in the region is the IRGA $424 \mathrm{RI}$, due to its genetic characteristics, it has great plasticity, it adapts well in all regions of the state of RS, it has high productivity, tolerant to blast (Pyricularia grisea Sacc), a cultivar highly requested by commercial producers (IRGA, 2019).

In sowing, the process is the same as in commercial crops, for this cultivar, the last fortnight of September and the month of october is the preferred time, density varies from 85 to $100 \mathrm{~kg}$ per ha, all used seed treatment with fungicides and insecticides. All sowing is done inline in the semi-direct sowing system, with soil prepared in autumn and dried with glyphosate herbicide before sowing. Weed control is done chemically, with pre-emergent action herbicides associated with a post-emergence one (SOSBAI, 2014).

Field isolation is observed, to avoid contamination of genetic origin, for irrigated rice cultivars the physical isolation must be at least 3 meters, thus avoiding the possibility of crosspollination. To preserve genetic purity, all use roguing where they remove atypical plants, other cultivars, and weedy rice (Oryza sativa L.) that are resistant to herbicide control, which is a very important process in cleaning seed areas. To avoid stains from glumes and fungal diseases, use 1 to 2 applications of fungicides in this cultivar. The fields are inspected by the certifiers in the flowering and pre-harvest period. The approved fields are harvested with a moisture content between $24 \%$ and $22 \%$ and sent to the Seed Processing Unit (IRGA, 2019).

The quality of the seed lot is directly reflected in the conditions of the field where it was produced. UBS does not correct any failures that occurred in the field. The last stage of the certified seed production process is processing. It is in the seed processing unit (UBS) that the product acquires, after removing contaminants, such as: immature, cracked or broken seeds or grains; weed seeds, inert material, plant pieces etc., classification to commercial standards. These unwanted materials need to be removed until the final seed production step. The removal of impurities from a batch is based on the use of physical differences between materials, such as size, mass, shape, color, and texture (OLIVEIRA et al., 1999).

Thus, maintaining the physiological, physical, and sanitary qualities until the final production process. After the processing process, the lots are stored, sampled by the certifying entity (IRGA), and analyzed, if they meet the minimum standard required by the Ministry of Agriculture, Livestock and Supply, they receive the certificate and can be sold (IRGA, 2016).

According to Vaughan et al. (1976), the quality of seeds is directly related to their hereditary characteristics and the ability of the processor to remove their impurities in them. Therefore, the quality of the seeds is affected by the cleaning method used and the type of equipment used in processing, which refers to the steps of preparation of seeds for commercialization, sowing or storage, comprising, in general, pre-cleaning, cleaning, classification and improvement of the physical qualities of seeds (BRAGANTINI, 1999). 
Thus, the present work aims to evaluate the physical and physiological qualities of seeds along the processing line of three certified seed production units in the region of the Internal Coastal Plain of Lagoa dos Patos in the state of Rio Grande do Sul.

\section{Material and Methods}

The present work was carried out in three seed processing units from different locations, these were identified as units $A, B$ and $C$. The samples were collected in July 2019, placed in previously identified paper boxes, at the exit of each equipment, along the processing line. Samples were collected after going through precleaning and drying. The irrigated rice cultivar used in the work was IRGA 424 RI.

Unit A: second generation certified seed collection - C2. Eight samples were collected at different points, first in the hopper, second point, exit from pre-cleaning, third point at the exit of the air and sieve machine, fourth point at the exit of the standardizer, fifth point at the disposal of the gravity table, sixth point at the exit of the gravity table, seventh point at the disposal of the electronics and eighth point at the exit of the electronics (bagging).

Unit B: In this unit, six samples were collected, of the same cultivar with certified seed production of first generation - C1. Where the first collection was carried out in the hopper, the second at the pre-cleaning exit, third collection at the air and sieve machine exit, the fourth at the standardizer exit, fifth at the gravity table disposal and finally the sixth, at the exit of the gravity table (bagging).

Unit C: In this processing unit, samples were collected at nine different points, first in the hopper, second in the pre-cleaning outlet, third in the air and sieve machine outlet, fourth in the trier outlet, fifth in the standardizer, sixth in the disposal of the gravity table, seventh in the output of the gravity table, eighth in the disposal of the electronics and ninth point in the output of the electronics (bagging).

Although it is the same cultivar, in the three units they come from different fields and lots, therefore, they were not compared with each other. The tests of moisture content and soil emergence were carried out in the teaching laboratory of seed analysis at the Federal University of Pelotas and the germination tests in paper towel substrate, purity, and analysis of contamination of other seeds in the laboratory of Instituto Rio Grande do Arroz in Pelotas.

Moisture content: Performed using the oven method $105+/-3$ oC for 24 hours, as prescribed in the Rules for Seed Analysis (BRAZIL, 2009), with the result expressed as an average percentage per sample.

Purity analysis: Prescribed in the seed analysis rules, that is, performed on a $70 \mathrm{~g}$ working sample where other seeds and inert materials were discarded, and the result expressed as a percentage (BRAZIL, 2009).

Other seeds by number: determined in a $700 \mathrm{~g}$ sample and described the amount and species of harmful seed found in the sample (BRAZIL, 2009).

Seedling emergence: two hundred seeds were used, divided into four sub-samples of fifty seeds, sown in plastic trays, containing soil + sand as substrate in a 2:1 ratio, counting after 15 days.

Germination test: Four replicates of one hundred seeds per sample were used, distributed on paper towels in a roll system, moistened in water in the amount equivalent to 2.5 times the weight of the paper, after being taken to the germinator previously set at $25 \stackrel{\circ}{\circ} \mathrm{C}$, followed by the prescriptions of the Seed Analysis Rules (BRAZIL, 2009) recording only the percentage of normal seedlings.

A completely randomized design was used, consisting of eight treatments in unit $A$, six treatments in unit $B$ and nine treatments in unit C. Analysis of variance was performed and means were compared using the Tukey test at the level of $5 \%$ probability, using the WinStat software.

\section{Result and Discussion}

Unit A: It was observed that the degree of moisture is similar in all treatments, on average $11.61 \%$. Seed moisture content is the most important factor affecting respiration rate, as it increases exponentially with increasing moisture content. When rice seeds are stored with a humidity lower than $13.5 \%$, the respiratory rate is minimized, but it does not eliminate it; and microorganism-induced deterioration is negligible. However, above this level, the increment is exponential (BAUDET, 2007).

Regarding the purity of the batch in this unit, after going through the pre-cleaning, it was found that they already had rates above $99 \%$, especially the electronics, which showed $100 \%$, showing good efficiency in this regard (Table 1). When analyzing the contamination by other 
species, it was found that there was considerable evolution along the processing line, except in the removal of weedy rice (O. sativa L.). When evaluating the germination (Table 2), it was found that the sample discarded by densimetric presented a lower percentage of germination than the other samples.

Similarity was found in the germination of samples collected in the hopper, pre-cleaning, MAP (Air and Sieve Machine), standardizer, electronic disposal. It was found that the germination percentage of the densimetric table was higher than the samples collected in the precleaning, standardizing, electronics disposal, and electronics outputs (final product). Passing through the density table allowed a significant increase in germination, and low germination of the sample was clearly observed when discarding the density table, (Table 2). The removal of lower density seeds can increase the performance of the seed lot (VAUGHAN et al., 1976), it was also observed by Bicca, Baudet and Zimmer, (1998) evaluating the effects of the density table, that there was an increase in hectoliter weight of the seeds collected in the upper discharge of this equipment.

In the soil emergence, (Table 2), it was observed that the samples collected in the hopper, discarding the densimetric and discarding the electronics were like each other and inferior to the others. The samples collected at the exit of the pre-cleaning, density and electronic table did not differ from each other as to the percentage emerged, being superior to the samples collected at the exit of the hopper, standardizer, density table disposal and electronic disposal. It was found that the sample collected at the MAP outlet showed a higher percentage of emergence than the other treatments.

Table 1. Characteristics of the physiological quality of rice seeds from each point sampled at UBS A.

\begin{tabular}{ccccc}
\hline UBS A & UR (\%) & Purity (\%) & $\begin{array}{c}\text { Other species by } \\
\text { number (700 g) * }\end{array}$ & Red rice ** \\
\hline Hopper & 11.7 & 97.4 & 55 & 0 \\
Pre-cleaning & 11.82 & 99.4 & 10 & 0 \\
Air and sieve & 11.33 & 99.8 & 2 & 0 \\
Standardizer (corrugated) & 11.9 & 99.8 & 3 & 0 \\
Density table. (Disposal) & 11.46 & 99.8 & 5 & 0 \\
Density table & 11.67 & 99.6 & 1 & 0 \\
Electronics (disposal) & 11.38 & 98.2 & 0 & 0 \\
Electronics (Packaging) & 11.63 & 100 & 0 & 1 \\
\hline
\end{tabular}

* Aeschynomene rudis L. ** Oryza sativa $\mathrm{L}$.

Table 2. Percentage of germination (germitest ${ }^{\circledR}$ ) and emergence (soil) in UBS A rice seeds.

\begin{tabular}{ccc}
\hline UBS A & Germination (\%) & Emergency (\%) \\
\hline Hopper & $86 \mathrm{ab}$ & 79 ef \\
Pre-cleaning & $83 \mathrm{~b}$ & $83 \mathrm{~b}$ \\
Air and sieve & $85 \mathrm{ab}$ & $89 \mathrm{a}$ \\
Standardizer (corrugated) & $83 \mathrm{~b}$ & $80 \mathrm{e}$ \\
Density table. (Disposal) & $75 \mathrm{c}$ & $78 \mathrm{f}$ \\
Density table & $87 \mathrm{a}$ & $87 \mathrm{~b}$ \\
Electronics (disposal) & $82 \mathrm{~b}$ & $79 \mathrm{ef}$ \\
Electronics (Packaging) & $82 \mathrm{~b}$ & $85 \mathrm{~b}$ \\
\hline CV (\%) & 1.95 & 0.91 \\
\hline
\end{tabular}

Means followed by different lowercase letters in the column differ from each other by Tukey's test (5\%).

Unit B: Relative humidity of the batch, on average $12.62 \%$. Analyzing the purity, it was observed that the seed already in the hopper was quite clean, with a percentage above $98 \%$, (Table 3) considering other species by number it was found that they had five seeds of Echinochloa crusgalli, in the hopper. It was verified that there was a great efficiency of the pre-cleaning machine in the suppression of this contaminating species. 
When analyzing the percentage of germination of the samples from Unit " $\mathrm{B}$ " (Table 4), it was observed that, when discarding the densimetric table, it presented the percentage of germination and emergence lower than the other samples. The sample collected in the hopper proved to be superior to the discard of the densimetric but inferior to the other treatments, the same occurred in the emergency test, except for the standardizer where they were similar.

The sample collected at the exit of the pre-cleaning machine showed higher germination and emergence than at the exit of the hopper and when discarding the densimetric, but lower than the MAP, standardizer and at the exit of the densimetric table. In the germination test it was also found that the MAP and standardizer did not differ from each other but were higher than the samples collected in the hopper, pre-cleaning and disposal of the density table, but lower than the final sample collected at the output of the density table being this one, superior to the other treatments. The same occurred in the emergency test, where the sample collected at the exit of the densimetric table was superior to the other equipment.

Therefore, it was found that there was a significant difference between the product at the output of the density table and the other equipment, with an increase in the percentage of germination and seedling emergence. When comparing with the material discarded by the table, we observed the low germination and seedling emergence, provided by the low specific mass of the grains. There was a considerable evolution in the physiological potential of the seeds as the lot follows the processing line, with a significant difference in the quality of the final product.

Table 3. Physiological quality characteristics of irrigated rice seeds from each point sampled at UBS B.

\begin{tabular}{ccccc} 
UBS B & UR (\%) & Purity (\%) & $\begin{array}{c}\text { Other species by } \\
\text { number (700 g) }\end{array}$ & Rice Red** $^{*}$ \\
\hline Hopper & 12.36 & 98.2 & 5 & 0 \\
Pre cleaning & 12.83 & 98.7 & 0 & 0 \\
Air and sieve & 12.63 & 99.9 & 0 & 0 \\
Standardizer & 12.94 & 99.9 & 0 & 0 \\
Density table. (Disposal) & 12.44 & 98.9 & 0 & 0 \\
Density table (Packaging) & 12.55 & 99.9 & 0 & 0 \\
\hline
\end{tabular}

* Aeschynomene rudis L.; Echinochloa crusgalli L. ** Oryza sativa L.

Table 4. Percentage of germination (germitest ${ }^{\circledR}$ ) and emergence (soil) in rice seeds for UBS B.

\begin{tabular}{ccc}
\hline UBS B & Germination (\%) & Emergency (\%) \\
\hline Hopper & $78 \mathrm{~d}$ & $68 \mathrm{~d}$ \\
Pre cleaning & $82 \mathrm{c}$ & $71 \mathrm{c}$ \\
Air and sieve & $86 \mathrm{~b}$ & $75 \mathrm{~b}$ \\
Standardizer & $86 \mathrm{~b}$ & $69 \mathrm{~d}$ \\
Density table. (Disposal) & $62 \mathrm{e}$ & $45 \mathrm{e}$ \\
Density table (Packaging) & $91 \mathrm{a}$ & $79 \mathrm{a}$ \\
\hline CV (\%) & 1.01 & 1.14 \\
\hline
\end{tabular}

Means followed by different lowercase letters in the column differ from each other by Tukey's test (5\%).

Unit C: The relative humidity of the batch presented an average of $11.75 \%$ for the samples. The level of purity of the batch was higher than 99.5\% after passing the pre-cleaning, significantly reducing the number of other species by number (Table 5). The equipment did not show efficiency in the elimination of weedy rice or red rice $(O$. sativa $\mathrm{L}$.), due to the homogeneity regarding the size, shape, and density of this weed, today, due to natural selection, the grain is very similar to the grains of the lot analyzed, even the electronics that separate by tone were not efficient. The electronics used in the units can be regulated in terms of sensitivity to remove this invader, it depends on the equipment used, but it also depends on the capacity of the processor in operating the equipment, eliminating contaminants with a minimum of residue. 
When we analyzed the germination, (Table 6) of the samples collected at the outputs of the equipment of this unit, it was found that when passing through the gravity table, the sample was higher than the others, its low was noted by the material discarded by this equipment. germination, superior only for the material collected at the exit of the pre-cleaning. At the electronic output, the germination percentage was higher than the other samples, except for the gravity table. The standardizer sample was significantly superior to the samples collected in the silo, pre-cleaning, MAP, Trier, gravity table disposal and electronics disposal, but it was inferior to the samples from the gravity and electronics table (bagging).
Observing the emergence of seedlings, (Table 6) in this unit, it was verified after the electronics (bag) the percentage of emergence was significantly higher than the other equipment. The disposal of electronics proved to be similar to the pre-cleaning sample, with a lower emergency than the electronics, superior to other equipment. Analyzing the low percentage of emergence of the material discarded on the gravity table, significantly lower than the others, it was found that the equipment was efficient in the elimination of seeds with low hectoliter weight.

Table 5. Characteristics of the physiological quality of rice seeds from each point sampled at UBS C.

\begin{tabular}{ccccc}
\hline UBS C & UR (\%) & Purity (\%) & $\begin{array}{c}\text { Other species by } \\
\text { number (700 g) }\end{array}$ & Rice Red** \\
\hline Silo & 11.39 & 98.2 & 3 & 0 \\
Pre-cleaning & 11.95 & 99.5 & 0 & 0 \\
Air and sieve & 12.06 & 100 & 0 & 0 \\
Trier & 11.46 & 99.9 & 0 & 0 \\
Standardizer & 11.58 & 100 & 0 & 0 \\
Density table. (discard) & 11.49 & 100 & 0 & 0 \\
Density table & 12.01 & 100 & 0 & 0 \\
Electronics (disposal) & 11.95 & 100 & 0 & 1 \\
Electronics (Packaging) & 11.86 & 100 & 0 & \\
\hline
\end{tabular}

*Aeschynomene rudis L.; Echinochloa crusgalli L. ** Oryza sativa L.

Table 6: Percentage of germination (germitest ${ }^{\circledR}$ ) and emergence (soil) in rice seeds at UBS C.

\begin{tabular}{ccc}
\hline UBS C & Germination (\%) & Emergency (\%) \\
\hline Silo & $64 \mathrm{fg}$ & $63 \mathrm{e}$ \\
Pre-cleaning & $61 \mathrm{~h}$ & $71 \mathrm{~b}$ \\
Air and sieve & $65 \mathrm{ef}$ & $65 \mathrm{~d}$ \\
Trier & $68 \mathrm{~d}$ & $66 \mathrm{~d}$ \\
Standardizer & $71 \mathrm{c}$ & $68 \mathrm{c}$ \\
Density table. (discard) & $63 \mathrm{~g}$ & $46 \mathrm{f}$ \\
Density table & $81 \mathrm{a}$ & $65 \mathrm{~d}$ \\
Electronics (disposal) & $66 \mathrm{e}$ & $70 \mathrm{~b}$ \\
Electronics (Packaging) & $78 \mathrm{~b}$ & $83 \mathrm{a}$ \\
\hline CV (\%) & 1.01 & 1.04 \\
\hline
\end{tabular}

Means followed by different lowercase letters in the column differ from each other by Tukey's test (5\%).

\section{Conclusions}

Processing improves the attributes of the lot, removing impurities and seeds of other species. The densimetric table improved the physical quality of the lots in the three units, obtaining a significant increase in the physiological potential.

\section{References}

BAUDET, L.; VILELA F. Seed processing units. SEED

News Magazine, XI, n.2, p.22-26, 2007. 
BICCA, F.M.; BAUDET, L.; ZIMMER, G.J. Separation of stained seeds from rice seed lots using the gravity table and its influence on sanitary quality. Brazilian Seed Magazine, v.20, n.1, p.106-111, 1998.

BRAZIL. Ministry of Agriculture, Livestock and Supply. Rules for seed analysis. Brasília: Mapa/ACS, 2009. 399 p.

IRGA. Certified Seeds. Lavoura Arrozeira Magazine, n.468, p.18-21, 2016.

IRGA. Rice Seeds in the South Zone of RS. Lavoura Arrozeira Magazine, n.471, p.22-24, 2019.

OLIVEIRA, A.; SADER, R.; KRZYZANOWSKI, F.C. Mechanical damage occurring in Soybean Processing and its Relationship with physiological quality. Revista Brasileira de Sementes, v.21, n.1, p.59-66, 1999. https://doi.org/10.17801/01013122/rbs.v21n1p59-66

SOSBAI. Irrigated rice: technical research recommendations for Southern Brazil/XXX Technical Meeting on Irrigated Rice Culture. Bento Gonçalves, RS: SOSBAI, 2014. 192 p

VAUGHAN, C.E; GREGG, B.R.; DELOUCHE, J.C. Processing and handling of seeds. Brasília: AGIPLAN, 1976. 195 p.

WELCH, G.B. Seed Processing in Brazil. February 1973. 205 p. 